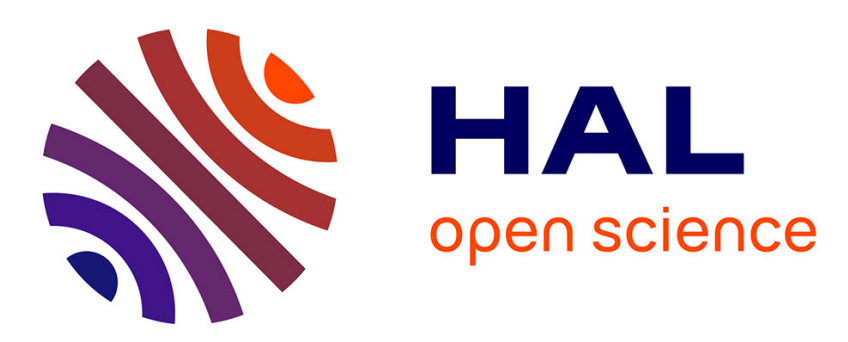

\title{
Dynamic Carbon Isotope Exchange of Pharmaceuticals with Labeled $\mathrm{CO} \_2$
}

Gianluca Destro, Olivier Loreau, Elodie Marcon, Frédéric Taran, Thibault Cantat, Davide Audisio

\section{- To cite this version:}

Gianluca Destro, Olivier Loreau, Elodie Marcon, Frédéric Taran, Thibault Cantat, et al.. Dynamic Carbon Isotope Exchange of Pharmaceuticals with Labeled CO_2. Journal of the American Chemical Society, 2019, 141 (2), pp.780-784. 10.1021/jacs.8b12140 . cea-02420524

HAL Id: cea-02420524 https://hal-cea.archives-ouvertes.fr/cea-02420524

Submitted on 20 Dec 2019

HAL is a multi-disciplinary open access archive for the deposit and dissemination of scientific research documents, whether they are published or not. The documents may come from teaching and research institutions in France or abroad, or from public or private research centers.
L'archive ouverte pluridisciplinaire HAL, est destinée au dépôt et à la diffusion de documents scientifiques de niveau recherche, publiés ou non, émanant des établissements d'enseignement et de recherche français ou étrangers, des laboratoires publics ou privés. 


\title{
Dynamic Carbon Isotope Exchange of Pharmaceuticals with Labeled $\mathrm{CO}_{2}$
}

\author{
Gianluca Destro, ${ }^{\dagger}$ Olivier Loreau, ${ }^{\dagger}$ Elodie Marcon,${ }^{\dagger}$ Frédéric Taran,${ }^{\dagger}$ Thibault Cantat,,$*$ Davide Audi- \\ $\operatorname{sio}^{\dagger *}$
}

${ }^{\dagger}$ Service de Chimie Bio-organique et Marquage (SCBM), CEA/DRF/JOLIOT, Université Paris Saclay, F-91191, Gif-surYvette, France. ${ }^{\ddagger}$ NIMBE, CEA, CNRS, Université Paris-Saclay, 91191 Gif-sur-Yvette, France

\section{Supporting Information Placeholder}

\begin{abstract}
A copper-catalyzed procedure enabling dynamic carbon isotope exchange is described. Utilizing the universal precursor $\left[{ }^{14} \mathrm{C}\right] \mathrm{CO}_{2}$, this protocol allows to insert, in one single step, the desired carbon tag into carboxylic acids with no need of structural modifications. Reducing synthetic costs and limiting the generation of radioactive waste, this procedure will facilitate the access to carboxylic acids containing drugs and accelerate early ${ }^{14} \mathrm{C}$-based ADME studies supporting drug development.
\end{abstract}

As part of drug discovery and development process, a full understanding of the fate of drug candidates is strictly required by most drug regulatory agencies (FDA, EMA) for marketing applications. ${ }^{1,2}$ The direct and traceless incorporation of a mass or radioactive tag, with no significant structural modifications, is of critical importance to follow the fate of the drug candidate, when administered to humans and animals. To date, the most effective and precise method to detect and quantify drugs and their metabolites both in vivo and in vitro relies on the introduction of isotopic labels. ${ }^{3}$ Because of their ubiquitous presence in organic compounds, carbon and hydrogen isotopes are unique tools to elucidate the absorption, distribution, metabolism, excretion (ADME) of the drug candidate. ${ }^{4,5}$ For human ADME studies and reactive metabolite screens, the use of carbon-14 $\left({ }^{14} \mathrm{C}\right)$ over tritium $\left({ }^{3} \mathrm{H}\right)$ isotopes is generally preferred to circumvent the loss of label due to the more rapid hydroxylation and exchange reactions in tritiated compounds, while featuring minimal isotope effects. ${ }^{6}$ The insertion of a carbon tag into organic molecules relies on the use ${ }^{14} \mathrm{C}$-carbon dioxide $\left(\mathrm{CO}_{2}\right){ }^{7}$ the universal precursor for all ${ }^{14} \mathrm{C}$ labeled compounds; yet, a poorly reactive and remarkably stable gas. ${ }^{8}$ Incorporation of ${ }^{14} \mathrm{C}$ usually leans on strong nucleophiles, such as the carboxylation of organolithium and Grignard reagents with $\mathrm{CO}_{2}$. This class of reactions, originally developed more than 100 years ago, ${ }^{9}$ is often not suitable to address modern challenges in radiochemistry and requires early installation of the carbon tag, because of functional group incompatibility. ${ }^{10}$ The hurdles involved in achieving late-stage carbon labeling of functionalized organic molecules and pharmaceuticals still represents a major challenge. ${ }^{11}$ Recent developments have mainly been focused on late-stage labeling with $\left[{ }^{14} \mathrm{C}_{\mathrm{CO}_{2}}\right.$ and the secondary building block K $\left[{ }^{14} \mathrm{C}\right] \mathrm{CN} .{ }^{12,13}$ Nevertheless, both strategies require the multistep synthesis of elaborated precursors, are limited to specific structures and lack of generality. An additional challenge to be considered is the stoichiometry of the reactions which must be reversed compared to the synthesis of the unlabeled materials, as the most precious reagent in the radiochemical reaction is $\left[{ }^{14} \mathrm{C}_{\mathrm{CO}_{2}}\right.$. While the emergence of hydrogen isotope exchange (HIE) methodologies for the direct insertion of deuterium and tritium into drugs has found widespread application in the pharmaceutical industry, ${ }^{14,15,16}$ the large majority of carbon-13 and carbon-14 labeled pharmaceuticals are still synthesized in multistep procedures. ${ }^{17}$ Besides being time consuming, these procedures generate large amounts of radioactive waste, thus incrementing the overall cost of the radiolabeling. The development of selective carbon isotope exchange (CIE) reactions would enable the synthesis of labeled compounds in a single operation without the need for precursors design and synthesis. Such processes would be particularly attractive for the pharmaceutical and agrochemical industry (Figure 1A). Carboxylic acids are highly abundant functional groups, commonly present in many major drug classes, including nonsteroidal anti-inflammatory drugs (NSAIDs), diuretics, anti-tumor agents and antibiotics. ${ }^{18}$ The development of carbon isotope exchange procedure on carboxylic acid derivatives with $\mathrm{CO}_{2}$ would be highly beneficial for radiolabeling.

In nature, the $\gamma$-resorcylate decarboxylase $(\gamma$-RSD) catalyzes the reversible decarboxylation of $\gamma$-resorcylate to resorcinol (1,3dihydroxybenzene) and $\mathrm{CO}_{2}$, at a zinc active site (Figure 1B). ${ }^{19,20}$ This biochemical transformation inspired us to adopt an analogous approach for the carbon isotopic exchange of carboxylic acids (Figure 1D). Decarboxylative cross coupling reactions have recently emerged as a method of choice for carbon-carbon bond formation. ${ }^{21}$ Aromatic carboxylates were shown to undergo thermal carbon dioxide extrusion to generate a highly reactive arylmetal species, in the presence of copper or silver salts. In the presence of a co-catalyst (i.e. Pd) a rapid transmetallation could take place and yield high value carbon-carbon bonds. ${ }^{22}$ We reasoned that, instead of trapping the aryl-metal species II with an appropriate co-catalyst, this intermediate could react with a labeled source of $\mathrm{CO}_{2}$ to yield labeled products, through a new CIE reaction (Figure $2 \mathrm{~A}$ ). We anticipated that the choice of the metal catalyst and the ancillary ligand would heavily influence the thermodynamics of the process as well as the competing protodecarboxylation of aryl-metal intermediate. In particular, the higher reactivity of aryl-metal species II compared to the carboxylate $\mathbf{I}$, as shown by the relative $\mathrm{pKa}$ of $o$-nitrobenzene and the corresponding carboxylic acid derivative, should require careful consideration and delicate balance. Because copper is an active decarboxylation catalyst, able to minimize proto-decarboxylation in cross-coupling reactions, we postulated that copper complexes could be active catalyst in a CIE reaction. ${ }^{23}$ 

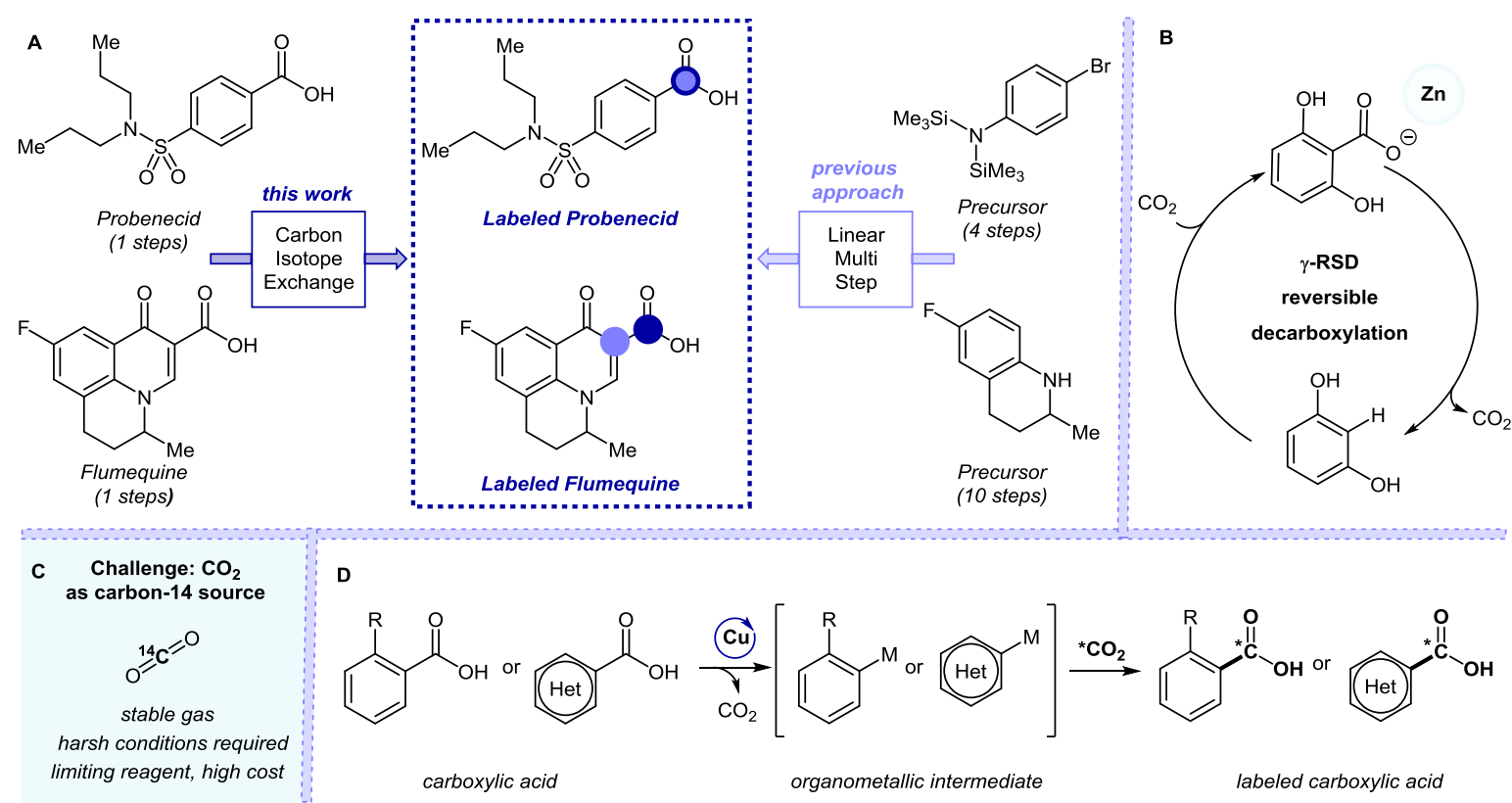

Figure 1: Catalytic reaction design. (A) Carbon labeling technologies for the insertion of the isotope into pharmaceutically relevant molecules. Light and dark blue circles represent the positions of isotopically labeled $\mathrm{C}\left(\mathrm{sp}^{2}\right)$ with CIE and linear multi step procedures, respectively. (B) Enzymatic reversible decarboxylation of $\gamma$-resorcylate to resorcinol. (C) Hurdles to overcome in the routine synthesis of carbon14 labeled compounds. (D) Proposed hypothesis for the mechanism of the dynamic CIE.

To test our hypothesis and identify systems capable of mediating CIE in carboxylic acids, 2-nitrobenzoic acid was selected as a model substrate, the electron withdrawing substituent in ortho position favoring a milder decarboxylation step. ${ }^{24}$ The cesium salt of the corresponding acid was utilized to limit a possible protodecarboxylation. Catalyst evaluation was initially conducted with $\left[{ }^{13} \mathrm{C}_{\mathrm{CO}_{2}}\right.$ gas, as a convenient and readily handled $\left[{ }^{14} \mathrm{C}\right] \mathrm{CO}_{2}$ surrogate. All of the reactions were conducted under standard conditions employing $20 \mathrm{~mol} \%$ of copper salt, $20 \mathrm{~mol} \%$ of ligand in NMP and DMSO with 3 equivalents of $\left[{ }^{13} \mathrm{C}\right] \mathrm{CO}_{2}$ at $150{ }^{\circ} \mathrm{C}$. The extent of isotopic exchange was determined after 2 hours using mass spectroscopy. Selected results from our screening experiments are summarized in the supporting information (Table S1 to S6). After evaluating a variety of phosphines, NHCs and multi-dentate nitrogen ligands, the proof-of-concept was obtained in presence of tetramethylethylenediamine (TMEDA, see SI) and $\left[{ }^{13} \mathbf{C}\right] 2$ could be isolated in $21 \%$ isotopic enrichment (IE), albeit only trace amounts of material could be isolated due to parasitic proto-decarboxylation. Surprisingly, a variety of ligands commonly utilized in copper-catalyzed decarboxylative cross coupling, such as bipyridines were poorly effective in CIE (see Table S2). After extensive optimization, we found that ligand L1, featuring a bisoxazoline scaffold, enabled the formation of $\left[{ }^{13} \mathbf{C}\right] 2$ in $75 \% \mathrm{IE}$, the highest possible enrichment at equilibrium. ${ }^{25}$

With the optimized conditions in hand, we sought to examine the scope of the CIE protocol with a library of aryl carboxylic acids. For the labeling of these substrates (Figure 3), the best conditions were found to be substrate-dependent, given a choice of two ligands (L1 and L2) and two solvents (DMSO and NMP/DMSO as a 4:1 mixture). As expected, the use of carboxylate salts was crucial to limit proto-decarboxylation.

The presence of methyl substituents on the ortho-nitro carboxylates (3-5) did not affect much the reactivity, though a slight decrease of the IE was observed when the substituent is in ortho $\left(\left[{ }^{13} \mathbf{C}\right] 6,23 \%\right.$ IE), as the presence of additional steric hindrance results in the decrease of the coordination of the carboxylate to the metal center (Figure 3 ). ${ }^{26}$

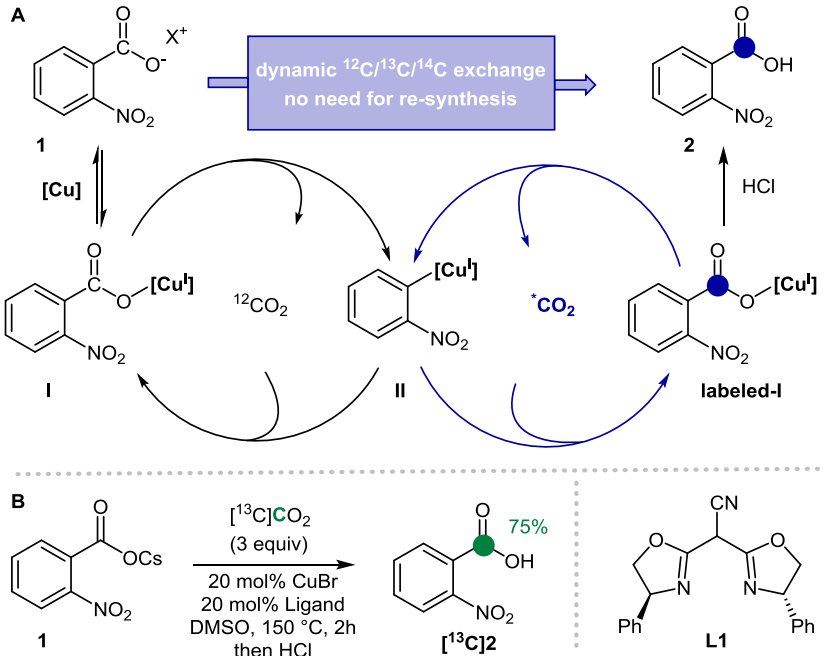

Figure 2: Reaction development. (A) Proposed catalytic cycle for the CIE protocol. (B) The colored circles (blue or green) and numbers denote the positions of the carbon atoms labeled and the percent incorporation of the carbon isotope, respectively. DMSO, dimethyl sulfoxide.

Stronger electron-donating methoxy groups were well tolerated and ${ }^{13} \mathrm{C}$ enriched products $\left[{ }^{\mathbf{1 3}} \mathbf{C}\right] \mathbf{7 - 9}$ were obtained in $39 \%$ to $64 \%$ IE. While the presence of iodo and bromo substituents is not suitable under the applied reaction conditions, products $\left[{ }^{13} \mathbf{C}\right] \mathbf{1 0}$, $\left[{ }^{13} \mathbf{C}\right] 11$ and $\left[{ }^{13} \mathbf{C}\right] \mathbf{1 2}$ bearing a $m$-chlorine, $p$-chlorine and $m$ fluorine were isolated with excellent IE $(66 \%, 59 \%, 70 \%)$. The presence of a nitro substituent in meta position was detrimental to the reactivity and only unlabeled material was recovered, under standard conditions. 


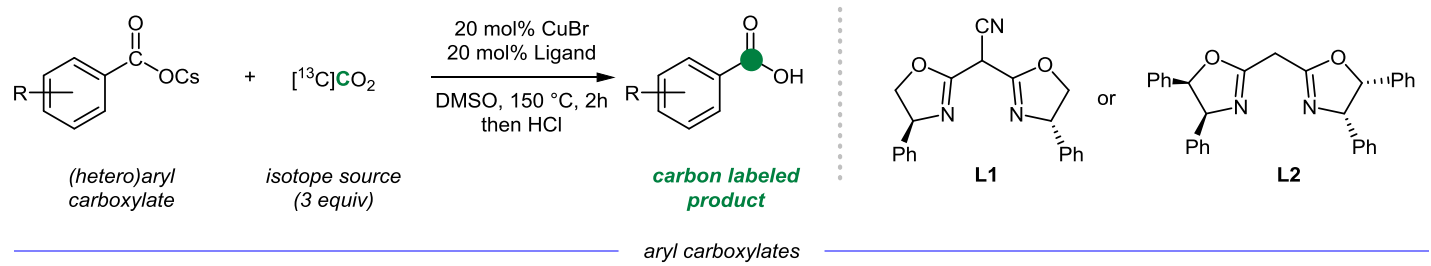<smiles>O=C(O)c1ccccc1[N+](=O)[O-]</smiles>

$\left[{ }^{13} \mathrm{C}\right] 2$<smiles>O=[14C](O)c1cccc([N+](=O)[O-])c1[N+](=O)[O-]</smiles>

$\left[{ }^{13} \mathrm{C}\right] 3$<smiles>Cc1ccc(C(=O)O)c([N+](=O)[O-])c1</smiles>

$\left[{ }^{13} \mathrm{C}\right] 4$<smiles>Cc1ccc([N+](=O)[O-])c(C(=O)O[13C](=O)[O-])c1</smiles>

$\left[{ }^{13} \mathrm{C}\right] 5$<smiles>Cc1cccc([N+](=O)[O-])c1C(=O)O</smiles>

$\left[{ }^{13} \mathrm{C}\right] 6$<smiles>COc1ccc([N+](=O)[O-])c(C(=O)O[Na])c1</smiles>

$\left[{ }^{13} \mathrm{C}\right] 7$<smiles>COc1ccc(C(=O)O)c([N+](=O)[O-])c1</smiles>

$\left[{ }^{13} \mathrm{C}\right] 8$<smiles>COc1cc(C(=O)O)c([N+](=O)[O-])cc1OC</smiles>

$\left[{ }^{13} \mathrm{C}\right] 9$<smiles>O=C(O)c1cc(Cl)ccc1[N+](=O)[O-]</smiles>

$\left[{ }^{13} \mathrm{C}\right] 10$<smiles>O=C(O)c1ccc(Cl)cc1[N+](=O)[O-]</smiles>

$\left[{ }^{13} \mathrm{C}\right] 11$<smiles>O=C(O)c1cc(F)ccc1[N+](=O)[O-]</smiles>

$\left[{ }^{13} \mathrm{C}\right] 12$<smiles>O=[14C](O)c1cccc([N+](=O)[O-])c1</smiles>

$\left[{ }^{13} \mathrm{C}\right] 13^{\mathrm{a}}$<smiles>O=[14C](O)c1cccc([N+](=O)[O-])c1[N+](=O)[O-]</smiles>

$\left[{ }^{13} \mathrm{C}\right] 14$<smiles>O=C(O)c1ccc([N+](=O)[O-])cc1</smiles>

$\left[{ }^{13} \mathrm{C}\right] 15$<smiles>COc1cc([N+](=O)[O-])ccc1C(=O)O</smiles>

$\left[{ }^{13} \mathrm{C}\right] 16$<smiles>O=[13C](O)c1ccccc1F</smiles>

$\left[{ }^{13} \mathrm{C}\right] 17$<smiles>COc1c(C(=O)O)ccc2ccccc12</smiles>

$\left[{ }^{13} \mathrm{C}\right] 18$

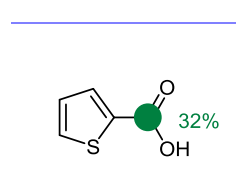

$\left[{ }^{13} \mathrm{C}\right] 19$

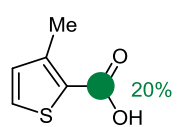

$\left[{ }^{13} \mathrm{C}\right] 20$

heteroaryl carboxylates

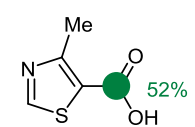

$\left[{ }^{13} \mathrm{C}\right] 21$

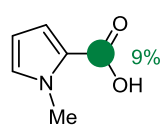

$\left[{ }^{13} \mathrm{C}\right] 22^{\mathrm{b}}$

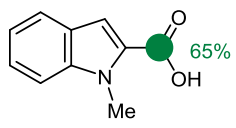

$\left[{ }^{13} \mathrm{C}\right] 23$<smiles></smiles>

$\left[{ }^{13} \mathrm{C}\right] 24$<smiles></smiles>

$\left[{ }^{13} \mathrm{C}\right] 25$<smiles>CC(=O)c1cc(=O)c2ccccc2o1</smiles>

$\left[{ }^{13} \mathrm{C}\right] 26$<smiles></smiles>

$\left[{ }^{13} \mathrm{C}\right] 27$<smiles>[13CH3]O[13CH]1OC1c1cc2c(ccc3ccccc32)oc1=O</smiles>

$\left[{ }^{13} \mathrm{C}\right] 28^{\mathrm{a}}$ UBP608<smiles>CCCN(CCC)S(=O)(=O)c1ccc(C(=O)O[14CH3])cc1</smiles>

$\left[{ }^{13} \mathrm{C}\right] 29^{\mathrm{a}}$ Probenecid<smiles>O=c1c([C@H]2O[C@@H]2O)cn2c3c(cc(F)cc13)CCC2[N+](=O)[O-]</smiles>

$\left[{ }^{13} \mathrm{C}\right] 30$ Flumequine

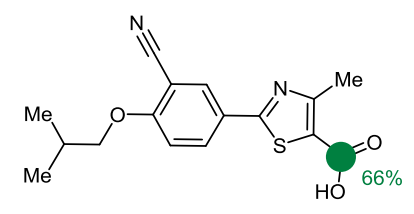

$\left[{ }^{13} \mathrm{C}\right] 31$ Febuxostat

Figure 3: Cu-catalyzed carbon-13 labeling of representative arenes, heteroarenes and pharmaceutical compounds. The green colored circles and numbers denote the positions of the carbon atoms labeled and the percent incorporation of the carbon-13 isotope, respectively. DMSO, dimethyl sulfoxide. Unless otherwise stated, L1 was utilized. ${ }^{\mathrm{a}}$ reaction temperature $190{ }^{\circ} \mathrm{C}$. ${ }^{\mathrm{b}} \mathbf{L} 2$ was utilized.

The reactivity could be partially restored by increasing the temperature to $190{ }^{\circ} \mathrm{C}$, and product $\left[{ }^{\mathbf{1 3}} \mathbf{C}\right] \mathbf{1 3}$ was isolated with $30 \%$ IE. The importance of the ortho substituent effect is highlighted in substrate 14, where the presence of the $o$-methyl allows the isolation of $\left[{ }^{13} \mathbf{C}\right] 14$ in $48 \%$ IE, without need of higher temperature.

Substrates $\left[{ }^{13} \mathbf{C}\right] \mathbf{1 5}$ and $\left[{ }^{\mathbf{1 3}} \mathbf{C}\right] \mathbf{1 6}$ bearing a nitro substituent in para position were isolated with $14 \%$ and $15 \%$ IE, respectively. Other substituents than the nitro group are effective under CIE protocol, however the weaker coordinating fluorine group in $\left[{ }^{13} \mathbf{C}\right] \mathbf{1 7}$, translated in a reduction of enrichment ( $31 \% \mathrm{IE})$. On the other hand, the use of 1-methoxy naphthalene core $\left[{ }^{\mathbf{1 3}} \mathbf{C}\right] \mathbf{1 8}$ gave an interesting IE of $39 \%$. Current limitations of the procedure are the presence of sole electrodonating methoxy substituents and substrates bear- ing labile protons which are unproductive or undergo protodecarboxylation (see SI for details).

To test the relevance of this novel CIE procedure, the labeling of important substructures in pharmaceuticals was tested. They include nitrogen-, oxygen- and sulphur-containing heteroarenes (19-27). In particular, methylthiazole $\left[{ }^{13} \mathbf{C}\right] 21$, benzofuranes$\left[{ }^{13} \mathbf{C}\right] \mathbf{2 4 - 2 5}$ and indole-2-carboxylates $\left[{ }^{\mathbf{1 3}} \mathbf{C}\right] \mathbf{2 3}$ were obtained in 43 to $65 \%$ IE. Chromone and coumarine carboxylate derivatives $\left[{ }^{\mathbf{1 3}} \mathbf{C}\right] \mathbf{2 6 - 2 7}$ were labeled in 29 and $27 \%$ IE, respectively. Pharmaceutically relevant compounds $\mathbf{2 8 - 3 1}$ were labeled in a single step using the CIE procedure with good IE (Figure 3).

A series of representative, commercially available pharmaceuticals and drug precursors were then labeled using $\left[{ }^{14} \mathrm{C}\right] \mathrm{CO}_{2}$, to 
evaluate the utility of the copper-catalyzed CIE over existing multistep methods (Figure 4A). The results were in good agreement with those obtained using stable carbon-13 isotope and did not require any further protocol optimization (Figure 3). 2Nitrobenzoic acid 2, a synthetic precursor of antipruritic drug crotamitone previously labeled with ${ }^{14} \mathrm{C}$ in four steps from $\left[{ }^{14} \mathrm{C}_{\mathrm{CO}_{2}}\right.$, ${ }^{27}$ was obtained by means of CIE with a high molar activity of $1506 \mathrm{MBq} \mathrm{mmol}^{-1}$ (Figure 4), meeting previously described requirements for use in preclinical candidate selection studies. ${ }^{28}$ Probenecid 29 was labeled in one single step from $\left[{ }^{14} \mathrm{C}_{\mathrm{CO}_{2}}\right.$ with a molar activity of $923 \mathrm{MBq} \mathrm{mmol}^{-1}$, more three times higher than what previous reported by Ellsworth and coworkers for metabolic disposition studies. ${ }^{29}$ Fluoroquinolone antibiotic flumequine $\mathbf{3 0}$ was successfully labeled on the carboxylic acid, which is essential for the pharmacological activity and metabolically stable,$^{30}$ with a molar activity of $1076 \mathrm{MBq} \mathrm{mmol}^{-1}$. The preparation of $\left[{ }^{14} \mathbf{C}\right] \mathbf{3 0}$ had previously involved a sequence of 10 linear steps from $\left[{ }^{14} \mathrm{C}\right] \mathrm{CO}_{2} \cdot{ }^{31}$ The current $\mathrm{CIE}$ procedure has the advantage of reducing dramatically the generation of radioactive waste, which are extremely polluting and expensive to dispose of. The ${ }^{14} \mathrm{C}$ labeling of benzofuran-2-carboxylic acid, synthetic precursor of neural nicotinic acetylcholine receptor agonist bradanicline, and febuxostat proceeded with good incorporation of the carbon tag.

A This work: $[\mathrm{Cu}]$-catalysed carbon- 14 exchange with $\left[{ }^{14} \mathrm{C}\right] \mathrm{CO}_{2}$

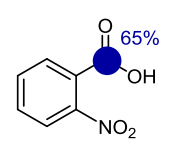

$\left[{ }^{14} \mathrm{C}\right] 2$ $1506 \mathrm{MBq} \mathrm{mmol}^{-1}$ (Crotamitone precursor)<smiles>CCCN(CCC(C)C)S(=O)(=O)c1ccc(C(=O)OC(=O)O)cc1</smiles>

$\left[{ }^{14} \mathrm{C}\right] 29$ Probenecid $923 \mathrm{MBq} \mathrm{mmol}^{-1}$

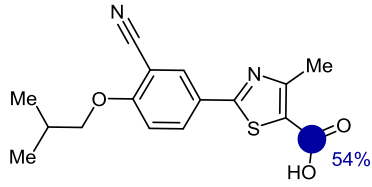

$\left[{ }^{14} \mathrm{C}\right] 31$ Febuxostat $1254 \mathrm{MBq} \mathrm{mmol}^{-1}$

B Previously reported multi-step synthesis

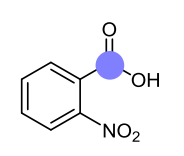

$\left[{ }^{14} \mathrm{C}\right] 2$

$192 \mathrm{MBq} \mathrm{mmol}^{-1}$

4 steps from ${ }^{14} \mathrm{CO}_{2}$

Ref. 27<smiles>CCCN(CCOC)S(=O)(=O)c1ccc(C(=O)O)cc1</smiles>

$\left[{ }^{14} \mathrm{C}\right] 29$ Probenecid $248 \mathrm{MBq} \mathrm{mmol}^{-1}$ 4 steps from ${ }^{14} \mathrm{CO}_{2}$ Ref. 28

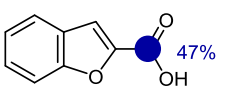

$\left[{ }^{14} \mathrm{C}\right] 24$ $1080 \mathrm{MBq} \mathrm{mmol}^{-1}$ (Bradanicline precursor)

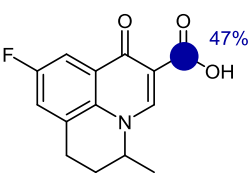

$\left[{ }^{14} \mathrm{C}\right] 30$ Flumequine $1076 \mathrm{MBq} \mathrm{mmol}^{-1}$
Figure 4: Cu-catalyzed carbon-14 labeling of pharmaceutical relevant molecules. (A) Reaction conditions as follows: $20 \mathrm{~mol} \%$ catalyst and ligand loading, see supporting information for detailed experimental procedures. (B) Comparison with multi step methods previously reported in the literature. The colored circles (dark or light blue) and numbers denote the positions of the carbon atoms labeled and the percent incorporation of the carbon isotope, respectively. Molar activities for each compound are expressed in $\mathrm{MBq} \mathrm{mmol}^{-1}$.

Radiolabeled compounds $\left[{ }^{14} \mathbf{C}\right] 24$ and $\left[{ }^{14} \mathrm{C}\right] 31$ were obtained with molar activities of 1080 and $1254 \mathrm{MBq} \mathrm{mmol}^{-1}$, in line with values acceptable for ADME studies. It is worth noting that compared to traditional multi-step procedures the current methodology shows a high degree of chemoselectivity, and is compatible with the presence of electrophilic moieties such as nitriles, ketones and sulfonamides.

At this early stage of development, this dynamic carbon isotope exchange protocol has already opened up new opportunities for the synthesis of carbon labeled drug intermediates and pharmaceuticals. Further extensions of the CIE can be expected from ligand design and the use of a variety of transition metal catalysts.

\section{ASSOCIATED CONTENT}

\section{Supporting Information}

The supporting information is available free of charge via the Internet at http://pubs.acs.org.

Experimental procedures and computational details

NMR spectra for obtained compounds

\section{AUTHOR INFORMATIONS}

\section{Corresponding Author}

*davide.audisio@cea.fr, thibault.cantat@cea.fr

\section{Notes}

The authors declare no competing financial interests.

\section{ACKNOWLEDGMENT}

This work was supported by CEA and by the European Union's Horizon 2020 research and innovation programme under the Marie Sklodowska-Curie grant agreement $N^{\circ} 675071$. The authors thank David-Alexandre Buisson and Céline Chollet for the excellent analytical support.

\section{REFERENCES}

(1) Maxwell, B. D.; Elmore, C. S. Eds. Radiosynthesis for ADME Studies; 461-471 (John Wiley \& Sons, Inc: Hoboken, 2012).

(2) Penner, N.; Klunk, L. J.; Prakash, C. Human Radiolabeled Mass Balance Studies: Objectives, Utilities and Limitations. Biopharm. Drug Dispos. 2009, 30, 185-203.

(3) Isin, E. M.; Elmore, C. S.; Nilsson, G. N.; Thompson, R. A.; Weidolf, L. Use of Radiolabeled Compounds in Drug Metabolism and Pharmacokinetic Studies. Chem. Res. Toxicol. 2009, 25, 532-542.

(4) Elmore, C. S.; Bragg, R. A. Isotope Chemistry; a Useful Tool in the Drug Discovery Arsenal. Bioorg. Med. Chem. Lett. 2015, 25, 167-171.

(5) Marathe, P. H.; Shyu, W. C.; Humphreys, W. G. The Use of Radiolabeled Compounds for ADME Studies in Discovery and Exploratory Development. Curr. Pharm. Des. 2004, 10, 2991-3008.

(6) Elmore, C. S., The Use of Isotopically Labeled Compounds in DrugDiscovery. Ed. Annu. Rep. Med. Chem. 2009, 44, 515-534.

(7) Zwiebel, N.; Turkevich, J.; Miller, W. W. Preparation of Radioactive $\mathrm{CO}_{2}$ from $\mathrm{BaCO}_{3}$. J. Am. Chem. Soc., 1949, 71, 376-377.

(8) Aresta, M. Carbon Dioxide as Chemical Feedstock (John Wiley \& Sons, 2010)

(9) Grignard, V. Compt. Rend. Acad. Sci. 130, 1322-1325 (1900).

(10) Bragg, R. A.; Sardana, M.; Artelsmair, M.; Elmore, C. S. New Trends and Applications in Carboxylation for Isotope Chemistry J. Label. Compd. Radiopharm. doi.org/10.1002/jlcr.3633.

(11) Kamen, M. D. Early History of Carbon-14: Discovery of this Supremely Important Tracer Was Expected in the Physical Sense but Not in the Chemical Sense. Science, 1963, 140, 584-590.

(12) (a) Dell Vecchio, A.; Caillé, F.; Chevalier, A.; Loreau, O.; Horkka, K.; Halldin, C.; Schou, M.; Camus, N.; Kessler, P.; Kuhnast, B.; Taran, F.; Audisio, D. Late-Stage Isotopic Carbon Labeling of Pharmaceutically Relevant Cyclic Ureas Directly from $\mathrm{CO}_{2}$. Angew. Chem. Int. Ed., 2018, 57, 9744-9748; (b) Bragg, R. A.; Sardana, M.; Artelsmair, M.; Elmore, C. 
S. New trends and applications in carboxylation for isotope chemistry. $J$. Label. Compd. Radiopharm. doi.org/10.1002/jlcr.3633.

(13) Derdau, V. New trends and applications in cyanation isotope chemistry. J. Label. Compd. Radiopharm. doi.org/10.1002/jlcr.3630.

(14) Atzrodt, J.; Derdau, V.; Kerr, W. J.; Reid, M. Deuterium- and Tritium-Labelled Compounds: Applications in the Life Sciences. Angew. Chem. Int. Ed. 2018, 57, 3022-3047.

(15) Pony Yu, R.; Hesk, D.; Rivera, N.; Pelczer, I.; Chirik, P. J. Ironcatalysed tritiation of pharmaceuticals. Nature, 2016, 529, 195-199.

(16) Loh, Y. Y.; Nagao, K.; Hoover, A. J.; Hesk, D.; Rivera, N. R.; Colletti, S. L.; Davies, I. W.; MacMillan, D. W. C. Photoredox-catalyzed

Deuteration and Tritiation of Pharmaceutical Compounds Science, 2017, 358, 1182-1187.

(17) Voges, R.; Heys, J. R.; Moenius, T. Preparation of Compounds Labeled with Tritium and Carbon-14 (John Wiley \& Sons, 2009).

(18) Sakaguchi, K.; Green, M.; Stock, N.; Reger, T. S.; Zunic, J.; King C. Glucuronidation of Carboxylic Acid Containing Compounds by UDPglucuronosyltransferase Isoforms Arch. Biochem. Biophys. 2004, 424, 219-225.

(19) Kourist, R.; Guterl, J.-K.; Miyamoto, K.; Sieber, V. Enzymatic Decarboxylation, an Emerging Reaction for Chemicals Production from Renewable Resources. ChemCatChem, 2014, 6, 689-701.

(20) Sheng, X.; Patskovsky, Y.; Vladimirova, A.; Bonanno, J. B.; Almo, S. C.; Himo, F.; Raushel, F. M. Mechanism and Structure of $\gamma$ Resorcylate Decarboxylase. Biochemistry, 2018, 57, 3167-3175.

(21) Wei, Y.; Hu, P.; Zhang, M.; Su, W. Metal-Catalyzed Decarboxylative C-H Functionalization. Chem. Rev. 2017, 117, 8864-8907.
(22) Gooßen, L. J.; Deng, G.; Levy, L. M. Synthesis of Biaryls via Catalytic Decarboxylative Coupling. Science, 2006, 313, 662-664.

(23) (a) Patra, T.; Maiti, D. Decarboxylation as the Key Step in C-C Bond-Forming Reactions. Chem. Eur. J. 2017, 23, 7382-7401; (b) Tortajada, A.; Juli-Hernndez, F.; Börjesson, M.; Moragas, T.; Martin, R. Transition-Metal-Catalyzed Carboxylation Reactions with Carbon Dioxide. Angew. Chem. Int. Ed. 2018, 10.1002/anie.201803186.

(24) Font, M.; Quibell, J. M.; Perry, G. J. P.; Larrosa, I. The Use of Carboxylic Acids as Traceless Directing Groups for Regioselective C-H Bond Functionalisation. Chem. Commun. 2017, 53, 5584-5597.

(25) D. Audisio, T. Cantat, G. Destro, EP18305407 (2018).

(26) Perry, G. J. P.; Larrosa, I. Recent Progress in Decarboxylative Oxidative Cross-Coupling for Biaryl Synthesis. Eur. J. Org. Chem. 2017, 3517-3527.

(27) Chaudhuri, N. K.; Potdar, S. V.; Ball, T. J. Synthesis of ${ }^{14}$ CLabeled Crotamiton. J. Label. Compd Radiopharm, 1982, 19, 75-82.

(28) Ellsworth, R. L.; Maxim, T. E.; Mertel, H. E. Synthesis of $p$-(di- $n$-propylsulfamyl)benzoic-1-(ring)- ${ }^{14} \mathrm{C}$ Acid and $p$-(di-n-propylsulfamyl) benzoic acid- ${ }^{14} \mathrm{C}$ (Probenecid- $\left.{ }^{14} \mathrm{C}\right) . \quad J . \quad$ Label. Compd. Radiopharm. 1978, 15, 111-115.

(29) Sharma, P. C.; Jain, A.; Jain, S. Fluoroquinolone Antibacterials: a Review on Chemistry, Microbiology and Therapeutic Prospects. Acta Pol. Pharm. 2009, 66, 587-604.

(30) Harrison, L. I.; Schuppan, D.; Rohlfing, S. R.; Hansen, A. R.; Gerster, J. F.; Hansen, C. S.; Funk, M. L.; Ober, R. E. Disposition of Radiolabeled Flumequine in Rat and Dog. Drug Metab. Dispos. 14, 555558 (1986). 


\section{TOC}

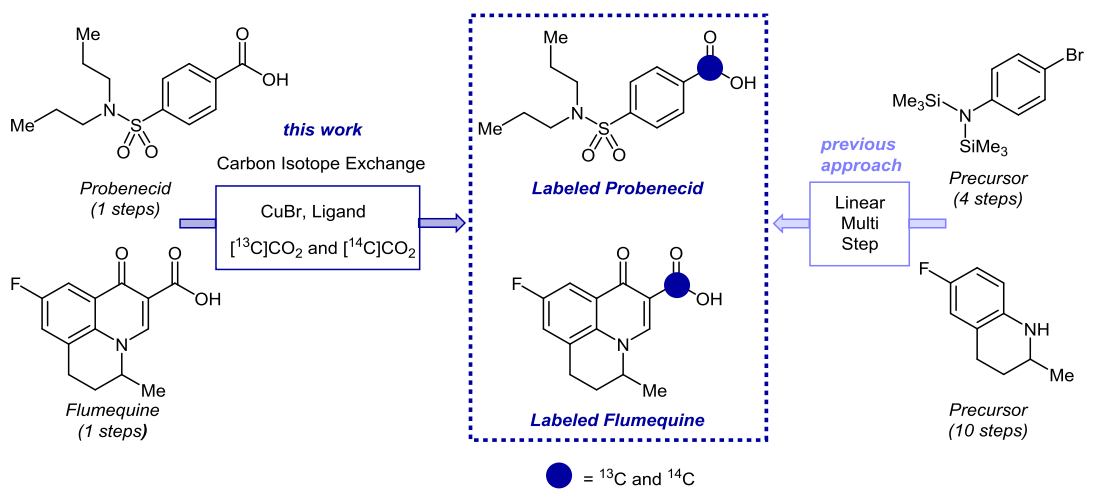

